\title{
Referential Cohesion in Donald Trump`s Speech Transcript
}

\author{
I Wayan Gede Agus Wirawan \\ English Department, Faculty of Arts, Udayana University \\ [agus8wirawan@gmail.com]
}

\begin{abstract}
Cohesion establishes the text or sentences and gives their meaning by the grammatical and lexical linking. Halliday and Hasan (1976) In Cohesion in English, identify five general categories of cohesive devices that are possibly implemented in texts: reference, ellipsis, substitution, lexical cohesion and conjunction. One of the cohesion meanings is reference. Reference is one of cohesive devices, and it contains the specific nature of the information needed to be retrieved for the comprehensive information. The problems discussed in this study are the type of reference applied in the speech transcripts and referential meaning presented in the speech transcripts of Donald Trump's Speech. The aims of the study were to find out the reference applied in the speech transcripts and referential meaning of the reference presented in the speech transcripts. The main theory used was Theory of Cohesion proposed by Halliday and Hasan (1976). The data in this study were taken from the website of Washington Post in form of transcripts. The data were collected using observation method and analyzed using qualitative method. There were two kinds of reference found in the speech; which were personal reference and demonstrative reference. The personal reference that occurred in the speech transcript included I, you, we, he, she, they, and it. Meanwhile, the demonstrative references that appeared in the speech transcript were this, these, there, here, now and the. These references were presented as endophoric, whether anaphoric or cataphoric. The comparative reference was absent. From this study, it can be concluded that referential cohesion takes an important role in a text or in this case speech transcripts, since the function of reference is to hold a text together and give its meaning.
\end{abstract}

Keyword: cohesion, referential cohesion, references, anaphoric, cataphoric

\begin{abstract}
Abstrak
Kohesi membentuk teks atau kalimat dan memberi makna melalui penafsiran gramatikal dan leksikal. Halliday dan Hasan (1976) dalam "Cohesion in English" mengidentifikasi lima kategori umum perangkat kohesif yang mungkin diterapkan dalam teks: referensi, elipsis, substitusi, kohesi leksikal dan konjungsi. Salah satu makna kohesi adalah referensi. Referensi adalah salah satu perangkat kohesif, dan berisi sifat spesifik berdasar pada informasi yang perlu diambil untuk mendapatkan informasi yang komprehensif. Masalah yang dibahas dalam penelitian ini adalah jenis referensi dan makna referensial yang disajikan dalam transkrip pidato oleh Donald Trump. Tujuan dari penelitian ini adalah untuk mengetahui jenis referensi yang diterapkan dalam transkrip pidato dan makna referensial yang disajikan dalam transkrip pidato. Teori utama yang digunakan adalah Teori Kohesi oleh Halliday dan
\end{abstract}


Hasan (1976). Data dalam penelitian ini diambil dari situs Washington Post dalam bentuk transkrip. Data dikumpulkan dengan metode observasi dan dianalisis dengan metode kualitatif. Ada dua jenis referensi yang ditemukan dalam pidato tersebut; yaitu referensi personal dan referensi demonstratif. Referensi personal yang muncul dalam transkrip pidato adalah I, you, we, he, she, they, dan it. Sementara itu, referensi demonstratif yang muncul dalam transkrip pidato adalah this, these, there, here, now dan the. Referensi tersebut dikategorikan sebagai endoforis referensi, baik anaforis atau kataforis. Referensi komparatif tidak ada di dalam transcript. Dari penelitian ini, dapat disimpulkan bahwa kohesi referensial berperan penting dalam teks atau dalam hal ini transkrip pidato, karena fungsi rujukan adalah membuat teks saling berkaitan dan memberi maknanya.

Kata kunci: Kohesi, kohesi referensial, referensi, anaforis, kataforis

\section{Background}

Linguistics is the scientific study of language and its components. The components of language are form, meaning, and context. Text analysis is one of language elements that can be analyzed. In linguistics, a text is used to refer to any passage, written or spoken. According to Halliday and Hasan (1976: 1-2), a text is best regarded as a semantic unit; a unit not of form but of meaning. In other words, according to Eggins (1994: 11), semantics is the basic purpose of language.

Cohesion establishes the text or sentences and gives their meaning by the grammatical and lexical linking. +

Halliday and Hasan (1976) In Cohesion in English identify five general categories of cohesive devices that are possibly implemented in texts: reference, ellipsis, substitution, lexical cohesion and conjunction. One of the cohesion meanings is reference. Reference is one of cohesive devices, and it contains the specific nature of the information needed to be retrieved for the comprehensive information. Halliday and Hassan (1976) describe that there are three types of reference; personal reference, demonstrative reference and comparative reference. Personal reference keeps track of function through the speech situation using pronouns (he, him, she, her, etc.) and possessive determiners (mine, yours, his, hers, etc.), demonstrative reference (this, that, those, these), comparative reference (general and specific comparison).

Based on "Cohesion in English" by Halliday and Hassan (1976), reference has two referential devices that can create cohesion, endophoric that is related to textual relation in which the source of the identification lies in the text and exophoric that is related to the contextual relation.

This study is concerned with the analysis of the reference in the Donald Trump's speech transcripts and more focuses on the types of reference. Since sentences are connected to each other, this study analyzed referential cohesion that refers to the semantic theory, because it is interesting to analyze what kind of relation found in the sentences and how they are connected to each other. Donald Trump speech transcript is an object that fits with this study because there is some phenomenon related to the use of reference in his speech.

\section{Problem of the Study}

a) What types of reference are applied in the transcripts of Donald Trump`s speech?

b) What referential meanings are presented in the transcripts of Donald Trump`s speech? 


\section{Aims of the Study}

a) To identify types of the reference applied in the transcripts of Donald Trump`s speech.

b) To analyze the referential meaning presented in the transcripts of Donald Trump's speech.

\section{Research method}

This study must be followed by certain academic procedures to establish a scientific writing. The Research methodology is the way to solve problems of this study. The research methodology that were used in this writing consists of four steps; they are data source, method and technique of collecting data, and method and technique of analyzing data, and method and technique of presenting data.

\subsection{Data source}

There were 2 Donald Trump's speech transcripts used as sources of the data in this study. The first data were taken from Donald Trump inauguration speech transcript, and it was downloaded from The Washington Post website. The Washington Post is an American daily newspaper located in the capital city of the United States of America. The data sources were taken from the official website of The Washington Post and the newspaper has particular emphasis on national politics. The second data were taken from Donald Trump's victory speech transcript and downloaded from The New York Times website. The New York Times is a well-known American daily newspaper and most of its contents emphasize on politics.

\subsection{Method and technique of collecting data}

The data were collected from the transcript of Donald Trump speech transcripts. The method used to collect the data was observation method. Observation method is collecting the data by reading the transcripts carefully. After observing the transcripts, the data were collected by identifying and note taking of the words that were relevant to the research from the speech transcripts.

\subsection{Method and technique of analyzing data}

The collected data were analyzed based on the adopted theories. The results of analysis were delivered qualitatively (determination of non-numerical information) and descriptively (describing the features of the data). The relevant data were analyzed based on reference theory of Cohesion in English by Halliday and Hasan (1976). Firstly, the data were read in order to find out the sentences containing reference items in the text. Second, the data or sentences containing reference items were classified in terms of the referential cohesion as to where it belongs to personal, demonstrative and comparative references. Third, the data were described to find out the referential meaning.

\subsection{Method and technique of presenting analysis}

The analysis of this study was presented in informal methods. In the informal method, the analysis was presented narratively based on theory of cohesion proposed by Halliday and Hasan (1976).

\section{Results and discussions}

There are two types of referential cohesion found on Donald Trump's speech transcript. The types of reference are categorized according to the theory of Cohesion in English by Halliday and Hasan (1976). The analysis of referential cohesion and its meaning are explained as follows: 


\subsection{Analysis of Personal Reference}

The personal references applied in the text are I, you, she, he, we, they and it. For further information, below is each of personal references analysis exposed in detail.

\section{a. Personal Reference $I$}

[5-1] The oath of office $\underline{I}$ take today is an oath of allegiance to all Americans. (speech 11)

From data observed, the reference $I$ belongs to first person and always takes the position as subject. It is classified as anaphoric reference because the source identification of information can be found by examining the content of the speech transcript. By examining the textual content, Donald Trump's Inauguration Speech as the title of the speech, this transcript is about the speech of Donald Trump in the Inauguration event. It can be identified that the personal reference $I$ refers to Donald Trump because this speech was delivered by the president of the United States of America, Donald Trump, in the inauguration event.

\section{b. Personal Reference}

[5-2] we are transferring power from Washington, D.C. and giving it back to you, the people. (speech 4)

In the example above there is a personal reference you and taking the position as a subject. The personal reference you refers to the addressee of Donald Trump's speech at the moment the speech was being delivered by him. Specifically, it cataphorically refers to the people. The addressee in this case can be classified as the citizen of America which is related to the Washington, D.C. as the capital city of the United States of America.

\section{c. Personal Reference $W e$}

[5-3] $\underline{\mathrm{We}}$, the citizens of America, are now joined in a great national effort to rebuild our country and restore its promise for all of our people. (speech 1)

In this example, sentence (2) of speech 1, the personal reference we can only refer to speaker and addressee. In this case, the personal reference we refers to Donald Trump as the speaker or the person who delivers the speech and the citizen of America as the addressee. Donald Trump identifies the addressee by clearly mentioning it on the first sentence in speech $1 ;$ We, the citizens of America. This is classified as cataphoric reference because we refer to the items mentioned after the reference.

\section{d. Personal Reference $\mathrm{He}$}

[5-4] But I'll tell you, Reince is really a star. And he is the hardestworking guy. And in a certain way, I did this - Reince, come up here. (speech 48)

There In the example above, the personal reference he takes the position as a subject with a determinative tendency to a specific person. Personal reference $h e$ in the example refers back to a specific person whose name is Reince. This reference is classified as anaphoric reference, since its function refers to preceding text.

\section{e. Personal Reference She}

[5-5] I've just received a call from Secretary Clinton. She congratulated us - it's about us - on our victory (speech 30)

The personal reference she here takes the position as a subject and refers to Secretary Clinton mentioned by the 
speaker in the first sentence. The personal reference she in the example above is classified as anaphoric reference because it refers back to the information mentioned before.

\section{f. Personal Reference They}

[5-6] we are grateful to President Obama and First Lady Michelle Obama for their gracious aid throughout this transition. They have been magnificent. (speech 3 )

There is a personal reference they that is transformed into their in the first sentence, and there is a personal reference they in the second sentence. Both are classified as anaphoric reference (to preceding the text) because personal reference they and their refer to President Obama and First Lady Michelle Obama mentioned by the speaker before.

\section{g. Personal Reference It}

[5-7] Today's ceremony, however, has very special meaning because today, we are not merely transferring power from one administration to another or from one party to another, but we are transferring power from Washington, D.C. and giving it back to you, the people. (speech 4)

The speaker or Donald Trump talks about transition or transferring power, he explains that transferring power is not merely from one party to another but from Washington D.C. to the people. In this part of speech there is one personal reference it and can be concluded that it represents the word power mentioned two times in the same sentence. The personal reference it here is classified as anaphoric reference (preceding text).

\subsection{Analysis of Demonstrative Reference}

The items of demonstrative reference that occur are this, these, that, there, now, here and the neutral the. Below is each demonstrative reference analysis exposed in detail.

\section{a. Demonstrative Reference This}

[5-1] Every four years, we gather on these steps to carry out the orderly and peaceful transfer of power, and we are grateful to President Obama and First Lady Michelle Obama for their gracious aid throughout this transition. (speech 3)

The word transition can be correlated with transfer of power, because the meanings of these words are relevant. In this case, this transition can be interpreted as orderly and peaceful transfer of power. The demonstrative reference this here refers to orderly and peaceful in the same sentence. This reference is classified as anaphoric reference because it refers to the items that has already mentioned.

\section{b. Demonstrative Reference That}

[5-2] The wealth of our middle class has been ripped from their homes and then redistributed all across the world. But that is the past. And now, we are looking only to the future. (speech 14)

The reference that in the example above refers back to The wealth of our middle class has been ripped from their homes and then redistributed all across the world. The reference that in this part of speech was used by Donald Trump to refer to a circumstance and in this case, demonstrative reference that is classified as anaphoric reference. 
c. Demonstrative Reference The

[5-3] We, the citizens of America, are now joined in a great national effort to rebuild our country and restore its promise for all of our people. (speech 1)

In the example above, there is a demonstrative reference the The demonstrative reference the is used for identifying citizen of America and is classified as a cataphoric reference (to following text).

\section{d. Selective Circumstantial Demonstrative Reference There, Here, Now}

[5-4] I said, Reince - and I know it, I know. Look at all those people over there (speech 48)

[5-5] This American carnage stops right here and stops right now. (speech 10)

The referential meaning of there refers to a place far from the speaker. Reference there in the example above can be interpreted as a location on which people gathered or it can be the addressee of the speaker.

The demonstrative reference here refers to the place where the speaker delivered the speech and the demonstrative reference now refers to the time when the speaker delivered his speech. The sentence in the example above can be interpreted into this American carnage stops right "at this place" and stops right "at this time."

\section{Conclusions}

Based on the previous analysis and discussion about reference, the following points can be stated as conclusions:

The referential cohesion that occurred in the Donald Trump's speech transcripts were Personal Reference and Demonstrative Reference. The items of personal reference that appeared were $I$, you, we, he, she, they and it. The items of demonstrative reference that occurred are this, these, that, there, now, here and the neutral the. Meanwhile, the comparative referential was absent in the speech transcripts.

Most of personal referential cohesion that appeared in the speech transcripts was presented as anaphoric reference which referred to the preceding text. Only few of them were classified as cataphoric references. Most of demonstrative references that occurred were categorized as cataphoric in which they referred to the following text.

The most presented type of reference was personal reference and it definitely gave significant influence on the speech transcripts. Reference played an essential role in order to form and build a good text and it could be concluded as the important component in the speech, to create cohesion within the speech.

\section{References}

Ari Karunia, I. A. 2012. Reference Used in the Article of Travel Trade Gazette Asia (Sarjana thesis). Universitas Udayana, Denpasar.

Beaugradne, Robert De and Dressler, Wolfgang U. 1981. Introduction to Text Linguistics. Longman Group Ltd, London

Eggins, Suzane. 1993. An introduction to Systemic Functional Linguistic. Bloomsbury Publishing, London.

Halliday, M.A.K. and Hassan, R. 1976. Cohesion in English. Longman Group Ltd, London. 
Halliday M.A.K and Hasan, R. 1985. Language, Context, and Text: Aspect of Language in a Social. Semiotic Perspective. Deakin University, Victoria.

Iqra, J., Assad, M. and Mudassar, I. 2013. Ellipsis, Reference \& Subtitution as Cohesive Devices The Bear by Anton Chekhov. ISSN-L: 2223-9553, ISSN:C2223-994 Vol. 4. No. 6. Available from: www.savap.org.pk $>2013(4.6-15)$ [Accessed 15 June 2017].

Michael, Angelina Subryan. 2013. Cohesion in News Articles: A Discourse Analysis Approach. ISSN: 200-3452 Vol. 2 No. 3. Available from: http://www.journals.aiac.org.au/in dex.php/IJALEL/article/view/864 [Accessed 12 December 2017].

Pebriyanti Widana. Kadek. 2010. Referential Cohesion in Crane's The Bridge to Yellow Sky (Sarjana thesis). Universitas Udayana, Denpasar.

Riemer, Nick. 2010. Introducing Semantics. Cambridge University Press. Available from:

https://archive.org/details/Introd ucingSemantics [Accessed 8 May 2017]

Ruri Sofyaniek, Ayu. 2011. The Analysis of Reference Items Used in Article of Bali and Beyond Magazine (Sarjana thesis). Universitas Udayana, Denpasar.

Blake, Aaron. 2017. Donald Trump's Full Inaguration Speech
Transcript, Annoted. Washington Post Website. Available from: www.washingtonpost.com/news/t he-fix/wp/2017/donald-trumpsfull-inaguration-speech-transciptannotated/ [Accessed 1 April 2017].

Federal News Services. 2016. Transcript: Donald Trump's Victory Speech. The New York Times Website. Available from: https://www.nytimes.com/2016/11 /10/us/politics/trump-speechtranscript.html [Accessed 5 August]. 